\title{
Stability of Celecoxib Oral Suspension
}

\author{
Ronald F Donnelly, Elena Pascuet, Carmen Ma, and Régis Vaillancourt
}

\section{ABSTRACT}

Background: Celecoxib is a selective cyclo-oxygenase 2 inhibitor that relieves pain without affecting platelet function, causing gastrointestinal toxic effects, or increasing the risk of bleeding.

Objectives: To develop a suspension formulation for oral celecoxib and to determine its physical and chemical stability when packaged in amber polyvinyl chloride (PVC) bottles and stored with refrigeration $\left(5^{\circ} \mathrm{C}\right)$ and at room temperature $\left(23^{\circ} \mathrm{C}\right)$.

Methods: The contents of celecoxib capsules were used to prepare a single suspension, with Ora-Blend used as the suspending and flavouring agent. The suspension $(10 \mathrm{mg} / \mathrm{mL})$ was then packaged in amber PVC bottles and stored at either $5^{\circ} \mathrm{C}$ or $23^{\circ} \mathrm{C}$. Samples were collected on days $0,7,14,21,27,56$, and 93 . Chemical stability was determined using a validated stability-indicating high-performance liquid chromatography method. At each sampling time, the suspensions were checked visually for changes in appearance (i.e., colour, layering, caking, and ease of resuspension), odour, and $\mathrm{pH}$.

Results: All of the suspensions were stable for at least 93 days, regardless of storage conditions. There were no apparent changes in physical appearance, nor were there any substantial changes in odour or $\mathrm{pH}$.

Conclusions: Suspensions of celecoxib (10 mg/mL in Ora-Blend) packaged in amber PVC bottles were stable for up to 93 days when stored at $5^{\circ} \mathrm{C}$ or $23^{\circ} \mathrm{C}$. A 3 -month expiry date has been established for this oral suspension on the basis of physical compatibility and chemical stability.

Key words: celecoxib, high-performance liquid chromatography, stability, suspension

\section{RÉSUMÉ}

Contexte : Le célécoxib est un inhibiteur sélectif de la cyclo-oxygénase 2 qui soulage la douleur sans altérer la fonction plaquettaire ni causer d'effets gastro-intestinaux toxiques ou accroître le risque de saignement.

Objectifs : Élaborer une suspension buvable de célécoxib et déterminer sa stabilité physique et chimique lorsqu'elle est conditionnée dans des flacons de polychlorure de vinyle (PVC) ambré et conservée au réfrigérateur $\left(5^{\circ} \mathrm{C}\right)$ et à la température ambiante $\left(23^{\circ} \mathrm{C}\right)$.

Méthodes : Le contenu de capsules de célécoxib a été utilisé pour préparer une seule suspension avec l'agent de suspension et aromatisant, Ora-Blend. La suspension $(10 \mathrm{mg} / \mathrm{mL})$ a été conditionnée dans des flacons de PVC ambré puis conservée à $5{ }^{\circ} \mathrm{C}$ ou à $23{ }^{\circ} \mathrm{C}$. Des échantillons ont été prélevés aux jours $0,7,14,21,27,56$ et 93. La stabilité chimique a été déterminée à l'aide d'une épreuve validée par chromatographie liquide haute performance. À chaque prélèvement d'échantillon, la suspension a été inspectée visuellement pour déceler tout changement d'apparence (c.-à-d., couleur, stratification, agglutination et facilité de remise en suspension), d'odeur et de $\mathrm{pH}$.

Résultats : Toutes les suspensions sont demeurées stables pendant au moins 93 jours, peu importe les conditions d'entreposage. On n'a observé aucun changement évident dans l'apparence des suspensions ni de changement substantiel dans l'odeur ou le $\mathrm{pH}$ des suspensions.

Conclusions : Les suspensions de célécoxib $(10 \mathrm{mg} / \mathrm{mL}$ dans de l'Ora-Blend) conditionnées dans des flacons de PVC ambré sont demeurées stables pendant une période allant jusqu’à 93 jours lorsqu'elles étaient entreposées à une température de $5^{\circ} \mathrm{C}$ ou de $23^{\circ} \mathrm{C}$. On a établi une date de péremption de trois mois pour cette suspension buvable d'après la compatibilité physique et la stabilité chimique.

Mots clés : célécoxib, chromatographie liquide haute performance, stabilité, suspension 


\section{INTRODUCTION}

Celecoxib is a nonsteroidal anti-inflammatory drug $\checkmark$ (NSAID) which functions by inhibiting the cyclooxygenase (COX) enzymes involved in the first step of the inflammation cascade. ${ }^{1}$ NSAIDs are important in treating and preventing mild or moderate pain in children and are highly effective in combination with a local or regional nerve block. ${ }^{1}$ The pain-relieving property of NSAIDs is due to inhibition of cyclo-oxygenase-2 (COX-2) isozymes, but inhibition of cyclo-oxygenase-1 (COX-1) isozymes causes gastrointestinal adverse effects. Celecoxib is a selective COX-2 inhibitor that relieves pain without causing any gastrointestinal toxic effects. In addition, it has no effects on platelet function, nor does it increase in the risk of bleeding. ${ }^{2}$ In Canada, the administration of celecoxib to children is an off-label use. However, given its proven effectiveness and safety profile in adults, this drug is being considered at the Children's Hospital of Eastern Ontario (in Ottawa, Ontario) as a coanalgesic for pediatric patients undergoing tonsillectomy and adenoidectomy. ${ }^{3}$

Clinicians frequently face a variety of challenges when giving medications to children. Dosing is most often based on the child's body weight, which results in a dose that is usually different from commercially available strengths. Most oral medications come in capsule or tablet form, neither of which allows for easy, if any, individualization of doses. Oral liquids are prescribed for children to allow customization of the dose and for children and adults to address difficulties in swallowing tablets or capsules. Therefore, extemporaneous compounding of oral liquids (e.g., suspensions) may be necessary, even though appropriate compounding formulas and stability data may be unavailable. Celecoxib is available only as $100-\mathrm{mg}$ and $200-\mathrm{mg}$ capsules; a liquid dosage form is not commercially available in Canada.

The purpose of this study was to develop an easy-toprepare compounding formula for celecoxib oral suspension and to use a validated stability-indicating high-performance liquid chromatography (HPLC) method to test its stability after extended storage in amber polyvinyl chloride (PVC) bottles under refrigeration $\left(5^{\circ} \mathrm{C}\right)$ and at room temperature $\left(23^{\circ} \mathrm{C}\right)$. Such a suspension would represent an accurate, easy-to-prepare dosage form of the medication, with a reasonable expiration date, for effective delivery to patients.

\section{METHODS Preparation of Suspensions}

Commercially available 100-mg celecoxib capsules (Celebrex, Pfizer Canada Inc, Kirkland, Quebec; lot C070985, expiry June 2010) were used to prepare the suspension. The contents of 20 capsules were ground to a fine powder using a mortar and pestle; the powder was then suspended in $200 \mathrm{~mL}$ of Ora-Blend (Paddock Laboratories Inc, Minneapolis, Minnesota; lot 7381009, expiry September 2009). Commercially available Ora-Blend contains equal volumes of a suspending agent (Ora-Plus) and a flavouring agent (Ora-
Sweet) that is palatable to children. The celecoxib suspension $(10 \mathrm{mg} / \mathrm{mL})$ was divided equally into 6 graduated amber PVC bottles (60-mL volume; Rigo Products, Division of Richards Packaging Inc, Mississauga, Ontario). Three bottles of the suspension were stored at $5^{\circ} \mathrm{C}$ (range $4^{\circ} \mathrm{C}$ to $7^{\circ} \mathrm{C}$ ) in a refrigerator, and the other 3 bottles were stored at $23^{\circ} \mathrm{C}$.

\section{Sample Collection}

On the day of preparation (day 0 ) and on days 7, 14, 21, 27, 56, and 93 after preparation, each bottle was shaken by hand for $1 \mathrm{~min}$, and one 5-mL sample was then collected from each bottle and transferred to a screw-capped amber bottle. After the samples had been obtained, they were stored at $-70^{\circ} \mathrm{C}$ until analysis by an HPLC method.

\section{Physical Compatibility}

The suspensions were examined at each sampling time for changes in odour (by smelling) and for changes in appearance, such as colour, layering, caking, and ease of resuspension (by unaided vision). The $\mathrm{pH}$ was determined using a $\mathrm{pH}$ meter (Accumet 25, Fisher Scientific Inc, Nepean, Ontario) that had previously been calibrated using a $\mathrm{pH} 4$ buffer (Fisher Scientific Inc; lot SC6236793, expiry September 30, 2008) and a pH 7 buffer (Fisher Scientific Inc; lot SC7134746, expiry May 31, 2009). On any given day, the accuracy of the meter had to be above $95 \%$ to proceed with testing.

\section{Chemical Stability Study HPLC System}

The HPLC system consisted of an isocratic pump (model LC-10ATvp, Shimadzu Scientific Instruments Inc, Columbia, Maryland), a photodiode array detector (model SPD-M20A, Shimadzu Scientific Instruments Inc), and an autoinjector (model Sil-10AXL, Shimadzu Scientific Instruments Inc). The solid phase of the system was a Luna C18 5- $\mu \mathrm{m}, 4.6 \times 250 \mathrm{~mm}$ column (Phenomenex, Torrence, California; lot 410754). The flow rate was set at $1.5 \mathrm{~mL} / \mathrm{min}$, and the wavelength was monitored at $254 \mathrm{~nm}$. Class-VP software (version 7.4, Shimadzu Scientific Instruments Inc) was used for data collection and analysis.

Standards and samples were analyzed in duplicate by a modified version of a previously published HPLC method. ${ }^{4}$ The modifications consisted of reducing the organic phase to $55 \%$ from $60 \%$, adding triethylamine $(1 \mathrm{ml} / \mathrm{L}$, HPLC-grade, Fisher Scientific Inc; lot 044898), changing the buffer system to citric acid from potassium dihydrogen phosphate, and adjusting the final $\mathrm{pH}$ to 3.5 instead of 4.0. The buffer system was changed because the phosphate had a tendency to precipitate in the mobile phase during storage. The citric acid buffer was prepared by dissolving $21.0 \mathrm{~g}$ of citric acid, monohydrate (BDH Inc, Toronto, Ontario; lot 120921/76774) and $1.24 \mathrm{~g}$ of sodium citrate, dihydrate (Medisca Pharmaceutique, SaintLaurent, Quebec; lot 18123/A), in $1000 \mathrm{~mL}$ of HPLC-grade 
water. Celecoxib stock solution was prepared by dissolving $28.6 \mathrm{mg}$ of reference material (Pfizer Incorporated, New York; compound SC-58635, assay 98\%, lot 1000832268) in $25 \mathrm{~mL}$ of a 50:50 mixture of acetonitrile and HPLC-grade water. Jadhav and others ${ }^{4}$ found that these solutions were stable for at least $48 \mathrm{~h}$. The internal standard was prepared by dissolving $51.0 \mathrm{mg}$ of ibuprofen powder (Professional Compounding Centers of America, Houston, Texas; lot CC000628, expiry June 27,2010$)$ in $10 \mathrm{~mL}$ of $50 \%$ acetonitrile.

\section{HPLC Assay Validation}

The stability-indicating capacity of the HLPC assay method was verified by monitoring forcibly degraded samples for interfering peaks. A stock solution of celecoxib for degradation was prepared by dissolving $49.3 \mathrm{mg}$ of reference material in $5 \mathrm{~mL}$ of $50 \%$ acetonitrile. This solution was then further diluted 1:10 in the solvent before preparation of 3 forced degradation samples. One sample was adjusted to $\mathrm{pH} 1.14$ with concentrated hydrochloric acid (BDH Inc; American Chemical Society [ACS] grade, lot 120834-78180). To the second sample, enough $5 \mathrm{~N}$ sodium hydroxide solution (Fisher Scientific Inc; certified, lot SC613544, expiry May 2008) was added to reach $\mathrm{pH}$ of 13.36 . To the final sample, $100 \mu \mathrm{L}$ of $30 \%$ hydrogen peroxide (Fischer Scientific Inc; ACS grade, lot 073191) was added. The acidic and alkaline samples were maintained at $40^{\circ} \mathrm{C}$ in a hot water bath; the oxidized sample was stored at $23^{\circ} \mathrm{C}$. An unaltered but diluted (1:50) celecoxib solution, prepared in the same way as the samples intended for degradation, was assayed as a time 0 or baseline sample. Each chemically treated sample was diluted 1:50 with mobile phase and tested a total of 10 times over $817 \mathrm{~h}$, and each chromatogram was inspected for the appearance of degradation peaks and changes in retention time and peak shape, as determined by calculation of the tailing factor. Degradation samples were diluted with mobile phase in an attempt to adjust the $\mathrm{pH}$ to a more acceptable range or to dilute out the oxidizing agent. Multiwavelength (230 and $254 \mathrm{~nm})$ and ultraviolet (UV) spectral analyses $(200-350 \mathrm{~nm})$ were used to test the purity of the parent peak in the degraded samples. Peaks were considered pure if the purity factor was greater than 0.9900. A blank sample of Ora-Blend, serially diluted first at $1: 10$ and then at 1:50, was analyzed for interfering peaks.

The HPLC method was further validated by preparing a 5 -point standard curve, on 5 separate days, and determining the precision of the method by calculating the coefficient of variance $(\mathrm{CV})$ for slopes and the average interday recovery ratio for the samples. Standards were prepared fresh on each day of analysis, by diluting enough celecoxib stock solution to generate final concentrations of $0.011,0.017,0.023,0.034$, and 0.046 $\mathrm{mg} / \mathrm{mL}$. Intraday analysis of the celecoxib stock solution, with 5 replicate injections at 3 different time points over a $24-\mathrm{h}$ period, was used to measure the daily precision of the method. The sensitivity of the method was determined, and the accuracy of the method was based on sample recovery testing.

\section{Stability Study}

Standards were prepared fresh on the day of analysis while the frozen samples were thawing to room temperature (for a minimum of $2 \mathrm{~h}$ ) after removal from the $-70^{\circ} \mathrm{C}$ freezer. The material in each bottle was resuspended by constant shaking, by hand, for about $1 \mathrm{~min}$. Aliquots (about $1 \mathrm{~g}$ each) were then accurately weighed with an analytical balance (model AE163, Mettler Instruments, Zurich, Germany) into $10-\mathrm{mL}$ volumetric flasks. Seven millilitres of $50 \%$ acetonitrile solution was added, and the solutions were sonicated for $10 \mathrm{~min}$. The resulting solutions were adjusted to a final volume of $10 \mathrm{~mL}$ with $50 \%$ acetonitrile solution. After mixing, $20 \mu \mathrm{L}$ of each sample was combined with $100 \mu \mathrm{L}$ of ibuprofen internal standard and $880 \mu \mathrm{L}$ of $50 \%$ acetonitrile solution. Then, $10 \mu \mathrm{L}$ of this mixture was injected onto the column. Samples were prepared in triplicate and assayed in duplicate $(n=6)$. A blank sample was run at the beginning of each batch analysis.

Area ratios of celecoxib to internal standard were calculated for each analysis and were used for further calculations. Data are reported as percentage of the initial drug concentration remaining at each time period for samples stored at $5^{\circ} \mathrm{C}$ and $23^{\circ} \mathrm{C}$. The final expiry dates assigned were based on the standard acceptable pharmaceutical end point of maintenance of no less than $90 \%$ of the initial drug concentration. ${ }^{5}$

\section{RESULTS \\ Physical Compatibility}

There was no appearance of layering or caking of the suspensions. The colour and odour did not seem to change over the course of the study. The $\mathrm{pH}$ of the suspensions did not change substantially for samples stored under the stated conditions. The $\mathrm{pH}$ range was 4.36 to 4.39 for refrigerated samples and 4.39 to 4.45 for samples stored at room temperature. These differences in $\mathrm{pH}$ are minimal and within the error of the equipment. This stability of $\mathrm{pH}$ was unsurprising, as the buffer in the Ora-Blend suspending agent would be expected to maintain the $\mathrm{pH}$.

\section{Chemical Stability HPLC Assay Validation}

Shortly after addition of sodium hydroxide to the degradation sample, the solution started to turn a yellowish colour, which indicated rapid degradation. However, after $817 \mathrm{~h}$ of exposure to acidic and alkaline conditions at $40^{\circ} \mathrm{C}$, the celecoxib had degraded by only $3 \%$ (Figure 1, panels A and B). The oxidized sample degraded by about $22 \%$ with storage at $23^{\circ} \mathrm{C}$ (Figure 1, panel C). Panel D of Figure 1 illustrates the chromatogram of the day 0 sample stored at room temperature. The retention time of the celecoxib peak did not change over $817 \mathrm{~h}$. The peak shape remained constant, and the tailing factor was maintained at about 1.20 for all celecoxib peaks. Multiwavelength analysis at 230 and $254 \mathrm{~nm}$ and comparison of celecoxib UV spectra from degradation samples with reference material spectra $(200-350 \mathrm{~nm})$ revealed that the parent peaks were pure, and all purity factors were above 0.9900 . 


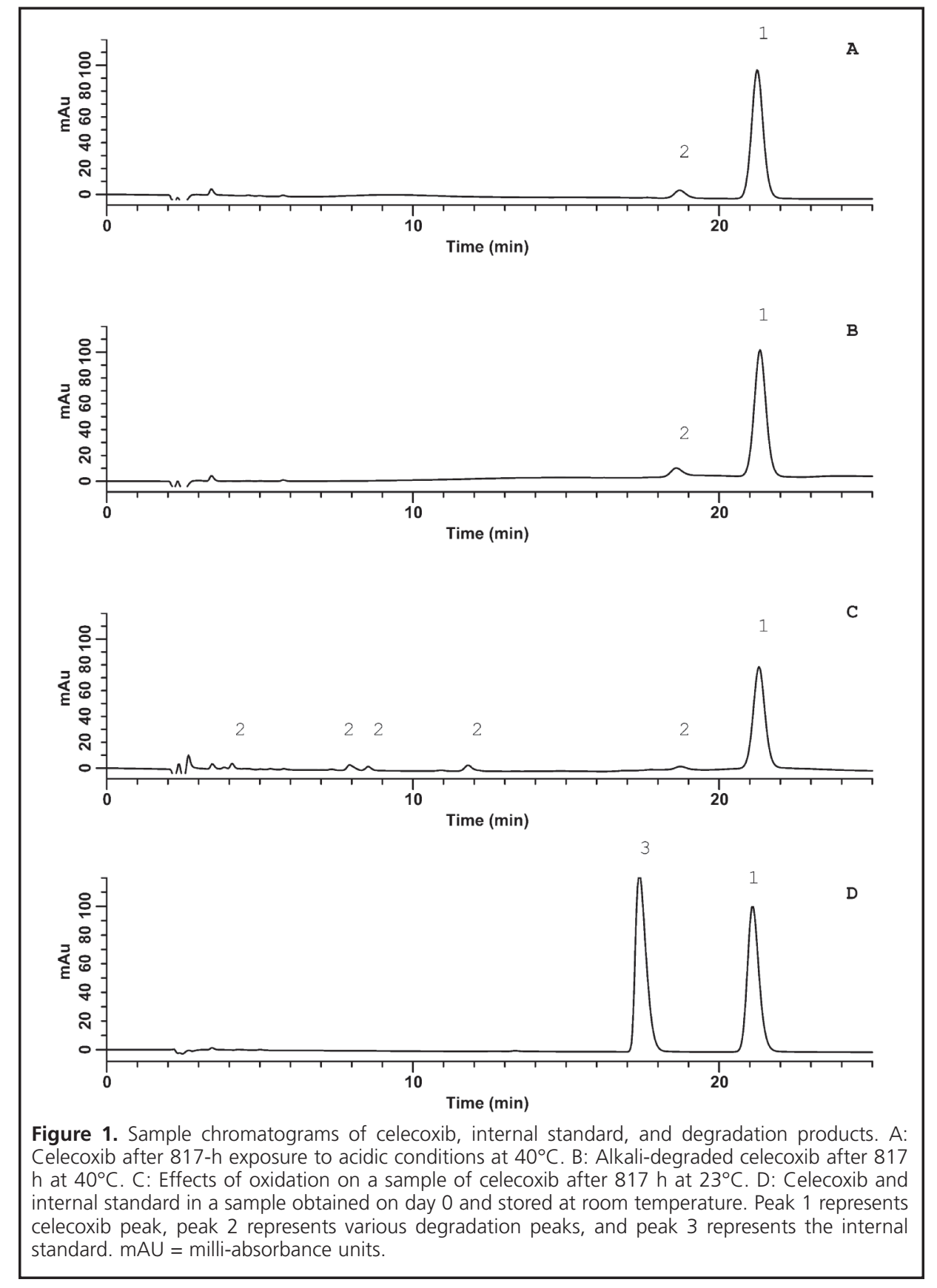

The interday CV was $2.2 \%$, based on the slopes of the celecoxib standard curves and the average peak area ratio calculations for the recovery samples from 5 separate days. Over a $24-\mathrm{h}$ period, the precision changed by no more than $1.1 \%$. The sensitivity of the assay method was determined to be $28.6 \mathrm{ng}$, and the accuracy was $95.0 \% \pm 1.4 \%$.

\section{Stability Study}

The results of the chemical stability study are summarized in Table 1. All celecoxib suspensions packaged in amber PVC bottles were stable for at least 93 days, regardless of storage conditions.

\section{DISCUSSION}

A comprehensive search of the published literature did not yield any compounding formulas or stability data for suspensions of celecoxib. This lack of information is of particular concern in the pediatric setting, because liquid dosage forms represent an accurate way to deliver the small doses that children need. In addition, information on product stability is important for ensuring that the active ingredient is not affected by long-term storage.

To address the possibility that the HPLC method used here could not distinguish the parent drug from the acidic and alkaline degradation products, the degradation samples were 
Table 1. Stability of Celecoxib Suspension $(10 \mathrm{mg} / \mathrm{mL})$ in Ora-Blend Stored in Amber Polyvinyl Chloride Bottles*

\begin{tabular}{lcc} 
Study Day & Room Temperature $\left(\mathbf{2 3 ^ { \circ } \mathrm { C } )}\right.$ & Refrigeration $\left(\mathbf{5}^{\circ} \mathbf{C}\right)$ \\
\hline Initial concentrationt $(\mathrm{mg} / \mathrm{mL})($ mean $\pm \mathrm{SD})$ & $10.1 \pm 0.55$ & $10.2 \pm 0.35$ \\
\hline 7 & $98.9 \pm 2.5$ & $99.2 \pm 1.2$ \\
14 & $100.8 \pm 2.0$ & $98.9 \pm 1.5$ \\
21 & $100.2 \pm 1.8$ & $97.8 \pm 2.1$ \\
27 & $97.8 \pm 1.1$ & $96.8 \pm 0.8$ \\
56 & $98.1 \pm 2.3$ & $97.5 \pm 0.9$ \\
93 & $99.4 \pm 1.0$ & $94.6 \pm 1.2$ \\
\hline
\end{tabular}

*Concentrations are reported as mean percent remaining \pm standard deviation (SD),

relative to day 0 values, based on 3 samples assayed in duplicate $(n=6)$.

tInitial concentrations were calculated by interpolation from the standard curve after least-squares

linear regression analysis of area ratio values (celecoxib/internal standard); based on 3 samples assayed in duplicate $(n=6)$.

analyzed using another previously published method, ${ }^{6}$ first with the same mobile phase as described previously ${ }^{6}$ and then with a different type of analytical column (phenylhexyl). The chromatograms generated by these 2 additional methods were no different from those generated by the original method. When Baboota and others ${ }^{6}$ used a mobile phase of $75 \%$ methanol, they obtained similar results: there was no degradation of the celecoxib under acidic conditions and a $22 \%$ decrease in concentration due to oxidization. Dhabu and Akamanchi ${ }^{7}$ took a more aggressive approach to degradation, refluxing the solutions for $8 \mathrm{~h}$; they observed reductions of $52 \%$ for the acidic sample, $70 \%$ for the basic sample, and $82 \%$ for the oxidized sample. Furthermore, using a mobile phase of $85 \%$ methanol they were able to selectively separate the parent compound from the degradation products. To further investigate the selectivity of the method used in the study reported here, degraded samples were separated using 2 separate thin-layer chromatography solvent systems. ${ }^{8}$ HPLC analysis of the isolated bands from the thin-layer chromatography plates revealed less than $0.8 \%$ interference with the celecoxib peak. The fact that 3 different HPLC systems produced similar chromatograms for the degradation samples supports the conclusion that this HPLC system was stability-indicating.

The quantitative results from this study indicate an expiration date of at least 93 days for celecoxib suspension $(10 \mathrm{mg} / \mathrm{mL})$ prepared with Ora-Blend stored either under refrigeration or at room temperature in amber polyvinyl chloride bottles. Standardization of the compounding formulation and determination of the stability of the suspension means that a reliable product with an acceptable expiry date can now be extemporaneously prepared.

\section{References}

1. Kokki H. Nonsteroidal anti-inflammatory drugs for postoperative pain: a focus on children. Paediatr Drugs 2003;5(2):103-123.

2. Turner S, Ford V. Role of the selective cyclo-oxygenase-2 (COX-2) inhibitors in children. Arch Dis Child Educ Pract 2004;89(2):ep46-ep49.
3. Nikanne E, Kokki H, Salo J, Linna TJ. Celecoxib and ketoprofen for pain management during tonsillectomy: a placebo-controlled clinical trial. Otolaryngol Head Neck Surg 2005;132(2):287-294.

4. Jadhav AS, Shingare MS. A new stability-indicating RP-HPLC method to determine assay and known impurity of Celecoxib API. Drug Dev Ind Pharm 2005;31(8):779-783.

5. Mollica JA, Ahuja S, Cohen J. Stability of pharmaceuticals. J Pharm Sci 1978;67(4):443-465.

6. Baboota S, Shakeel F, Ahuja A, Ali J, Ahmed S, Shafiq S. Development and validation of a stability-indicating HPLC method for analysis of celecoxib in bulk drug and microemulsion formulation. Acta Chromat 2007;18:116129.

7. Dhabu PM, Akamanchi KG. A stability-indicating HPLC method to determine Celecoxib in capsule formulations. Drug Dev Ind Pharm 2002;28(7):815-821.

8. Bebawy LI, Moustafa AA, Abo-Talib NF. Stability-indicating methods for the determination of doxazosin mezylate and celecoxib. J Pharm Biomed Anal 2002;27(5):779-793.

Ronald F Donnelly, MSc(Chem), BSC(Pharm), is Product Development Pharmacist, Department of Pharmaceutical Sciences, The Ottawa Hospital (Civic Campus), Ottawa, Ontario.

Elena Pascuet, MSc, is Pharmacy Project Coordinator with the Department of Pharmacy, Children's Hospital of Eastern Ontario, Ottawa, Ontario.

Carmen Ma, BScPhm, is a Critical Care Pharmacist with the Department of Pharmacy, Children's Hospital of Eastern Ontario, Ottawa, Ontario.

Régis Vaillancourt, PharmD, is the Director of Pharmacy with the Children's Hospital of Eastern Ontario, Ottawa, Ontario.

\section{Address correspondence to:}

Ronald F Donnelly

Department of Pharmaceutical Sciences

The Ottawa Hospital

1053 Carling Avenue

Ottawa ON K1Y 4E9

e-mail: rdonnelly@ottawahospital.on.ca

\section{Acknowledgements}

This project was funded externally by the Medbuy Corporation Endowment/Bursary 2007 Fund. Pfizer Incorporated generously donated the celecoxib reference material for this study. 